\title{
Rhizobium vignae sp. nov., a symbiotic bacterium isolated from multiple legume species
}

\author{
Correspondence \\ En Tao Wang \\ entaowang@encb.ipn.mx
}

\author{
Da Wei Ren, ${ }^{1}$ Wen Feng Chen, ${ }^{1}$ Xin Hua Sui, ${ }^{1}$ En Tao Wang ${ }^{1,2}$ and Wen \\ Xin Chen ${ }^{1}$
}

\author{
${ }^{1}$ State Key Laboratories for Agrobiotechnology/College of Biological Sciences, China Agricultural \\ University, Beijing, 100193, PR China \\ ${ }^{2}$ Departamento de Microbiología, Escuela Nacional de Ciencias Biológicas, Instituto Politécnico \\ Nacional, 11340 México D. F., México
}

\begin{abstract}
A group of rhizobial strains isolated from nodules of multiple legume species grown in different geographical regions of China had identical 16S rRNA genes. Phylogenetic analysis based on the 16S rRNA gene sequences showed that the novel strains formed a subclade in the genus Rhizobium together with Rhizobium galegae, Rhizobium huautlense and Rhizobium alkalisoli, with $99.8 \%$ gene sequence similarity between the strains. The DNA-DNA relatedness values between the representative strain CCBAU $05176^{\top}$ and $R$. galegae ATCC $43677^{\top}, R$. huautlense S02 ${ }^{\top}$ and $R$. alkalisoli CCBAU $01393^{\top}$ were $22.6 \%, 8.9 \%$ and $15.9 \%$, respectively. The novel strains were distinguished from recognized species of the genus Rhizobium by using a polyphasic approach, including PCR-based restriction fragment length polymorphism analysis (RFLP) of the 16S-23S intergenic spacer (IGS), phenotypic and physiological tests, sequence comparisons of housekeeping genes and cellular fatty acid profiles. Therefore, it is suggested that this group of strains represents a novel species for which the name Rhizobium vignae sp. nov. is proposed. The type strain is CCBAU $05176^{\top}\left(=\right.$ HAMBI $3039^{\top}=$ LMG $\left.25447^{\top}\right)$.
\end{abstract}

Rhizobia are Gram-negative rod-shaped bacteria that induce the formation of nodules on the roots or stems of leguminous plants. Within the nodules, they convert atmospheric nitrogen to ammonia and then provide organic nitrogenous compounds such as glutamine or ureides to the plant. In the past two decades, the description of novel taxa of root- and stem-nodule bacteria has been accelerated by the adoption of a polyphasic taxonomic approach (Vandamme et al., 1996) to characterize new isolates from various leguminous plants. The genus Rhizobium, proposed for a group of fast-growing, nodule-forming rhizobia, was firstly described by Frank (1889) and at the time of writing contained 34 species, including the recently described species Rhizobium alkalisoli (Lu et al., 2009), Rhizobium tibeticum (Hou et al., 2009) and Rhizobium mesosinicum (Lin et al., 2009).

Abbreviation: NJ, neighbour joining.

The GenBank/EMBL/DDBJ accession numbers for the partial 16S rRNA, atpD, recA, and g/nll gene sequences of Rhizobium vignae sp. nov. CCBAU 05176 ${ }^{\top}$ are GU128881, GU128888, GU128902 and GU128895, respectively. The $16 \mathrm{~S}$ rRNA, recA and g/n/l gene sequence accession numbers for the six additional novel strains are GU128882GU128887, GU128903-GU128908 and GU128896-GU12901, respectively.

Supplementary figures and a supplementary table are available with the online version of this paper.
In previous studies, seven strains of root-nodule bacteria isolated from Vigna radiata (Zhang et al., 2006), Astragalus dahuricus, Astragalus oxyglottis (Zhao et al., 2008) and Desmodium microphyllum ( $\mathrm{Gu}$ et al., 2007) grown in different regions of China were classified into the genus Rhizobium and were demonstrated to be closely related to Rhizobium galegae by using amplified rDNA restriction analysis (ARDRA). The nodulation ability of the strains on their hosts of origin was confirmed in each of the previous studies. In the present study, the taxonomic status of these strains was clarified by analysis of the 16S-23S rRNA intergenic spacer (IGS-RFLP) and housekeeping gene ( atpD, recA and $g \ln I I$ ) sequences, cellular fatty acid profiles, DNA-DNA relatedness and the determination of phenotypic characteristics.

Seven novel strains (Table 1) and the reference strains were purified and cultured using a standard procedure on yeast mannitol agar (YMA) medium (Vincent, 1970). They were maintained on YMA at $4{ }^{\circ} \mathrm{C}$ for temporary storage and in $20 \%(\mathrm{w} / \mathrm{v})$ glycerol at $-80{ }^{\circ} \mathrm{C}$ for long-term storage.

Total DNA from each strain was prepared as described by Terefework et al. (2001) and used as the template in the amplification of the 16S rRNA gene, 16S-23S intergenic spacer and atpD (ATP synthase subunit beta), $\operatorname{rec} A$ (recombinase A protein) and $g \ln I I$ (glutamine synthetase II) housekeeping genes. 
Table 1. Bacterial strains used in this study and their relevant characteristics

\begin{tabular}{|c|c|c|c|}
\hline Strain & Host plant & Geographical origin & Reference \\
\hline \multicolumn{4}{|l|}{ R. vignae sp. nov. } \\
\hline CCBAU $05176^{\mathrm{T}}$ & Astragalus dahuricus & Hebei province, China & Zhao et al. (2008) \\
\hline CCBAU 45248 & Vigna radiata & Luoyang, Henan province, China & Zhang et al. (2006) \\
\hline CCBAU 45111 & Vigna radiata & Xixia, Henan province, China & Zhang et al. (2006) \\
\hline CCBAU 45071 & Vigna radiata & Lankao, Henan province, China & Zhang et al. (2006) \\
\hline CCBAU 83006 & Astragalus oxyglottis & Xinjiang Autonomous Region & Zhao et al. (2008) \\
\hline R. galegae ATCC $43677^{\mathrm{T}}$ & Galega orientalis & Finland & Lindström (1989) \\
\hline R. huautlense $\mathrm{S} 02^{\mathrm{T}}$ & Sesbania herbacea & Mexico & Wang et al. (1998) \\
\hline R. alkalisoli CCBAU $01393^{\mathrm{T}}$ & Caragana intermedia & Inner Mongolia, China & Lu et al. (2009) \\
\hline R. cellulosilyticum ALA10B2 ${ }^{\mathrm{T}}$ & Populus alba & Spain & García-Fraile et al. (2007) \\
\hline
\end{tabular}

The 16S rRNA genes of all seven strains were amplified and sequenced using the primers P1 and P6 according to the procedure of Tan et al. (1997). The sequences were aligned with those held in the GenBank database using the CLUSTAL $\mathrm{W}$ program in the MEGA 4.0 software suite (Tamura et al., 2007). Aligned sequences were analysed using the same software to produce a Jukes-Cantor distance (Jukes \& Cantor, 1969) and to construct an optimal unrooted tree using the neighbour-joining (NJ; Saitou \& Nei, 1987) and maximum-parsimony methods. The robustness of the tree topology was calculated from bootstrap analysis using 1000 replications (Felsenstein, 1985). As no significant topological differences were found between the phylogenetic trees constructed using the two methods, only the tree constructed by using the NJ method after distance analysis of aligned sequences is shown (Fig. 1). The 16S rRNA gene sequences of all seven novel strains were identical and were closely related to $R$. galegae ATCC $43677^{\mathrm{T}}, R$. alkalisoli CCBAU $01393^{\mathrm{T}}$ and $R$. huautlense $\mathrm{S} 02^{\mathrm{T}}$ with $99.8 \%$ gene sequence similarities (Table 2).

It is generally considered that the high sequence variation of the 16S-23S IGS region allows discrimination between closely related strains (Kwon et al., 2005). This fragment was amplified from the seven novel strains and reference strains by PCR with primers FGPS6 (5'-GGAGAGTTAGATCTTGGCTCA-3') and 23S-38 (5'-CCGGGTTTCCCCATTCGG-3') (Rasolomampianina et al., 2005). The procedure described by Kwon et al. (2005) was applied for PCR amplification. Aliquots $(5-8 \mu \mathrm{l})$ of PCR products were digested separately with the restriction endonucleases MspI, HaeIII and Hhal during $4-6 \mathrm{~h}$ at $37{ }^{\circ} \mathrm{C}$. The digested fragments were separated by electrophoresis at $100 \mathrm{~V}$ for $4 \mathrm{~h}$ in $3 \%(\mathrm{w} / \mathrm{v})$ agarose gels $\left(20 \mathrm{~cm} \times 8 \mathrm{~cm}, 5 \mathrm{~V} \mathrm{~cm}^{-1}\right)$ and were photographed under UV light after ethidium bromide staining. The restriction patterns were normalized, combined and clustered using the GelCompar II version 3.0 software package (Applied Maths). The Dice coefficient and the UPGMA method were used to obtain the restriction pattern based dendrogram (see Supplementary Fig. S1 in IJSEM Online). The data indicated that the seven novel strains were divided into two RFLP patterns sharing $92 \%$ similarity, which clearly differed from phylogenetically related species of the genus Rhizobium ( $\leqslant 70 \%$ similarity).

Housekeeping genes ( $a t p D, g \ln I, g \ln I I, r e c A$, dnaK etc.) throughout the genome are being used increasingly to investigate the phylogeny of bacteria. Most recently, multilocus sequence typing (MLST) of ten housekeeping genes was performed and this method was demonstrated to be superior to multilocus enzyme electrophoresis (MLEE) (van Berkum et al., 2006) and DNA-DNA hybridization (Martens et al., 2008). In the present study, PCR amplification and sequencing of partial atpD, recA and $g \ln I I$ genes was performed according to Gaunt et al. (2001) and Turner \& Young (2000). The sequence similarities of the $a t p D, r e c A$ and $g \ln I I$ genes were $98.6-100 \%$ between the seven strains of the novel group and were less than $96 \%$ between members of the novel group and the type strains of recognized species (Table 2). Phylogenetic trees were constructed based on these sequences by using the NJ method after distance analysis of aligned sequences according to the Kimura two-parameter (Kimura, 1983) model. The phylogenetic position of the seven strains was similar in the analyses of the three housekeeping genes and they formed a lineage most related to $R$. galegae as shown in the $\operatorname{atp} D$ gene sequence phylogenetic tree (Fig. 2) (recAand $g \ln I I$-based phylogenetic trees are available as Supplementary Figs S2 and S3 in IJSEM Online). The seven novel strains showed high gene sequence similarities with each other for the three housekeeping genes (Table 2), but they were not clones of the same strain because they were isolated from different regions and different legume species (Table 1). They also showed close relationships with $R$. galegae, which were consistent with the phylogenetic tree based on 16S rRNA gene sequences (Fig. 1). Strain CCBAU $05176^{\mathrm{T}}$ shared $95.6,96.0$ and $94.4 \%$ sequence similarities with $R$. galegae ATCC $43677^{\mathrm{T}}$ for the atpD, recA and $g \ln I I$ genes, respectively (Table 2).

DNA-DNA hybridization is considered as a standard method to define bacterial species (Graham et al., 1991; Wayne et al., 1987). In this study, all seven novel strains 


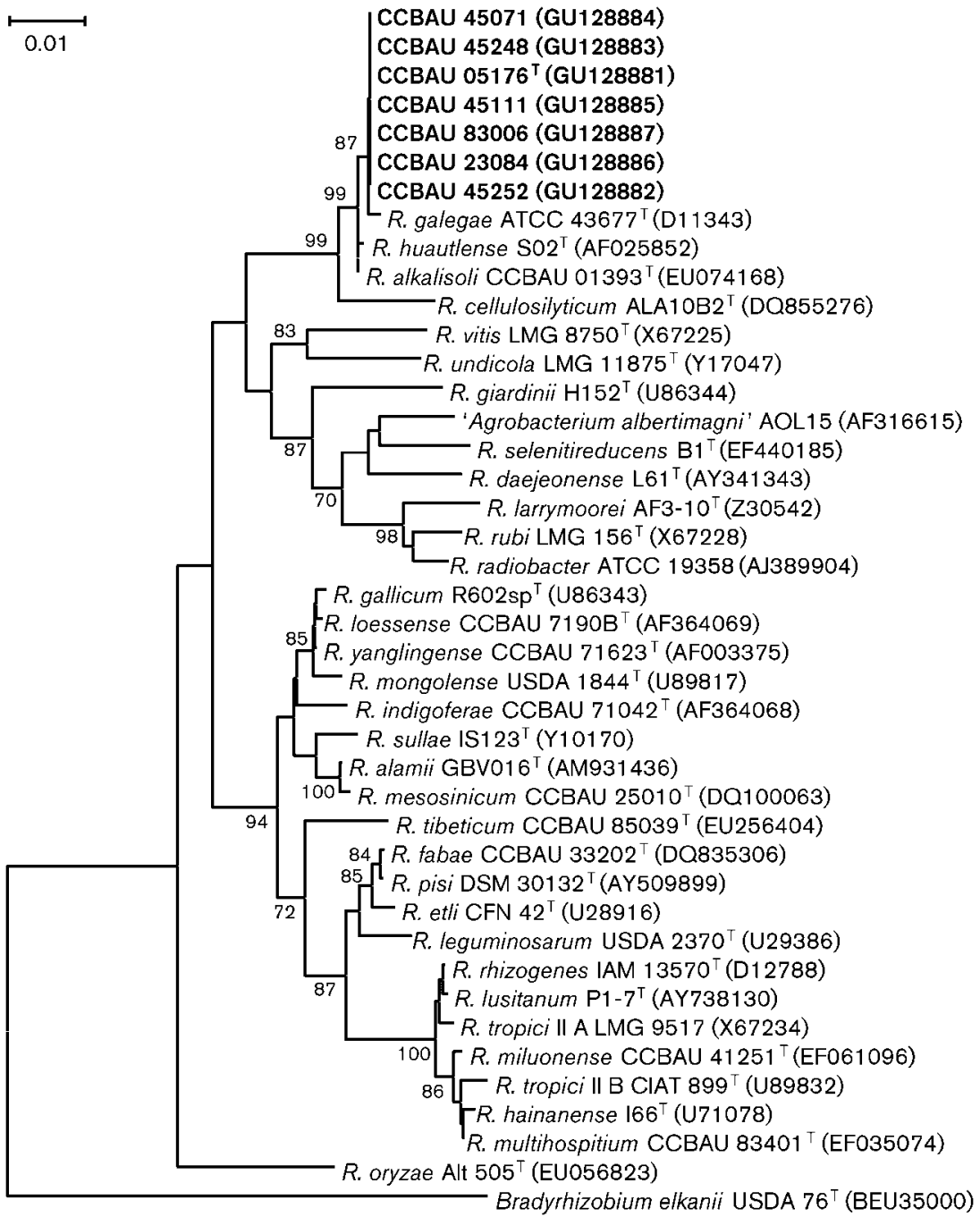

Fig. 1. Phylogenetic tree constructed from 16S rRNA gene sequences with the Kimura two-parameter and NJ methods showing the relationships among the seven novel strains (bold type) and recognized species of the genus Rhizobium. Bootstrap values $>70 \%$ are indicated at the nodes. Bradyrhizobium elkanii USDA $76^{\top}$ was used as outgroup. Bar, 0.01 expected changes per site. and the reference strains of related species were used for DNA-DNA hybridization experiments. Total DNA was extracted from each strain by using the method of Marmur (1961) and the DNA G + C mol\% was determined using the thermal denaturation method $\left(T_{\mathrm{m}}\right)$. DNA from Escherichia coli K-12 was used as the standard (Marmur
\& Doty, 1962). The DNA G $+\mathrm{C}$ contents of the novel strains varied between 59.1 and $61.6 \mathrm{~mol} \%\left(T_{\mathrm{m}}\right)$, which was in the range previously determined for members of the genus Rhizobium (Jordan, 1984). DNA-DNA relatedness within the novel group and between the novel strains and related species of the genus Rhizobium was determined

Table 2. Sequence similarities (\%) for $16 \mathrm{~S}$ rRNA, atpD, recA and g/n/l genes and DNA-DNA relatedness (\%) between strains of the novel group and reference strains

NA, not available.

\begin{tabular}{|c|c|c|c|c|c|}
\hline \multirow[t]{2}{*}{ Strain } & \multicolumn{5}{|c|}{ Similarity (\%) with strain CCBAU $05176^{\mathrm{T}}$} \\
\hline & 16S rRNA & $\operatorname{atpD}$ & $\operatorname{rec} A$ & $g \ln I I$ & DNA-DNA relatedness \\
\hline Other six strains in the group & 100 & $98.6-100$ & 100 & $99.6-100$ & $88.0-94.0$ \\
\hline R. galegae ATCC $43677^{\mathrm{T}}$ & 99.8 & 95.6 & 96.0 & 94.4 & 22.6 \\
\hline R. huautlense $\mathrm{S} 02^{\mathrm{T}}$ & 99.8 & 93.0 & 89.5 & $\mathrm{NA}$ & 8.9 \\
\hline R. alkalisoli CCBAU $01393^{\mathrm{T}}$ & 99.8 & 95.8 & 89.5 & 89.7 & 15.9 \\
\hline R. cellulosilyticus ALA10B $2^{\mathrm{T}}$ & 98.3 & 90.8 & 85.1 & NA & 18.5 \\
\hline
\end{tabular}




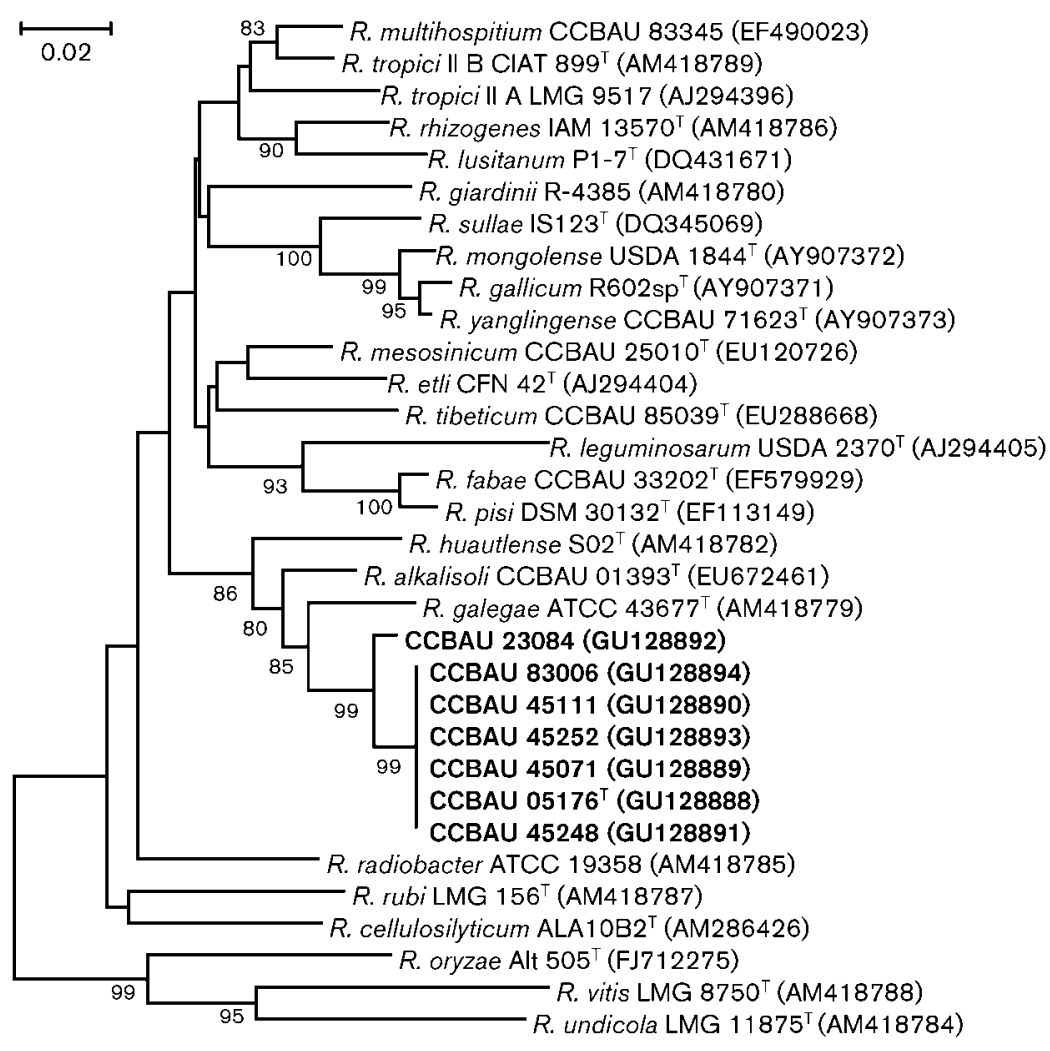

Fig. 2. Phylogenetic tree constructed from atpD gene sequences showing the relationships between the novel group and closely related bacteria. The tree was constructed by the NJ method with a Kimura two-parameter distance matrix. Bootstrap values (\%) are based on 1000 replicates and values $>70 \%$ are indicated at the nodes. Bar, 0.02 expected changes per site. using the spectrophotometric method (De Ley et al., 1970). The representative strain CCBAU $05176^{\mathrm{T}}$ had DNA-DNA relatedness values of $88-94 \%$ with the other six strains in the novel group and had similarities of $8.9-22.6 \%$ with the type strains of recognized species (Table 2). Therefore, the seven novel strains formed a single genomic species which differed from recognized species based on the recommendation of a threshold value of $70 \%$ DNA-DNA relatedness for the delineation of separate species (Graham et al., 1991; Wayne et al., 1987).

To clarify whether the seven novel strains could be defined as a separate species, phenotypic features were determined in comparison with the related species according to the methods described by Gao et al. (1994). The features tested included the utilization of sole carbon and nitrogen sources, resistance to antibiotics, tolerance of $\mathrm{NaCl}$, the $\mathrm{pH}$ and temperature ranges for growth (Gao et al., 1994) and other physiological and biochemical tests. The phenotypic characterization showed that a combination of various features (Table 3) could differentiate the novel group of strains from closely related species of the genus Rhizobium. Members of the novel group could not use melibiose as the sole carbon source but the reference strains of the related species could. Some differences were also observed between the strains within the novel group. The four strains that originated from $V$. radiata grown in Henan province had identical features and differed from the other three strains by an inability to use dulcitol, DL-asparagine and L-proline as sole carbon sources, sensitivity to erythromycin $\left(50 \mu \mathrm{g} \mathrm{ml}^{-1}\right)$ and an inability to grow at $\mathrm{NaCl}(2 \%, \mathrm{w} / \mathrm{v})$ or $\mathrm{pH} 10$. These differences could relate to the geographical or host origins as was reported previously for Sinorhizobium meliloti (Yan et al., 2000) and Sinorhizobium fredii (Peng et al., 2002) populations in Xinjiang, China.

Cellular fatty acid profiles are commonly used to discern and describe novel bacterial species (de Lajudie et al., 1998; Quan et al., 2005; Tighe et al., 2000). In this study, the fatty acid composition of cells was determined by the standard method of the Microbial Identification System (MIDI) and the detailed results are available in Supplementary Table S1 (see IJSEM Online). Two strains of the novel group were included in this analysis. Five fatty acids were detected in strain CCBAU $05176^{\mathrm{T}}$ and 30 fatty acids (including those found for strain CCBAU $05176^{\mathrm{T}}$ ) were detected in cells of strain CCBAU 45252. The difference of fatty acid patterns between these two strains was consistent with the divergence in their phenotypic characteristics and indicated the existence of variable strains in the novel group. The value of fatty acid content analysis for the taxonomy of the novel group needs to be evaluated further with more strains. According to this analysis, the fatty acids $\mathrm{C}_{16: 0}, \mathrm{C}_{16: 0} \mathrm{~N}$ alcohol, $\mathrm{C}_{19: 0}$ cyclo $\omega 8 c$ and summed feature $8\left(\mathrm{C}_{18: 1} \omega 7 c\right.$ and/or $\left.\mathrm{C}_{18: 1} \omega 6 c\right)$ were present as the main compounds $(1.31-46.97 \%)$ in strains CCBAU $05176^{\mathrm{T}}$, CCBAU 45252, $R$. galegae HAMBI $540^{\mathrm{T}}$ and $R$. huautlense $\mathrm{S}_{0} 2^{\mathrm{T}}$, but the proportions were variable between the strains. For example, the content of summed feature 8 was $33.06 \%, 16.09 \%$, $18.91 \%$ and $46.97 \%$ for strains CCBAU $05176^{\mathrm{T}}$, CCBAU 
Table 3. Distinctive features of Rhizobium vignae sp. nov. and the most closely related species of the genus Rhizobium

Taxa: 1, Rhizobium vignae sp. nov. ( $n=7) ; 2$, R. galegae ATCC $43677^{\mathrm{T}}$; 3, R. huautlense $\mathrm{S}_{2} 2^{\mathrm{T}} ; 4$, R. alkalisoli CCBAU $01393^{\mathrm{T}}$. +, All strains positive; -, all strains negative. The number of positive strains is indicated where the characteristic was variable.

\begin{tabular}{|c|c|c|c|c|}
\hline Characteristic & 1 & 2 & 3 & 4 \\
\hline \multicolumn{5}{|l|}{ Substrates used as sole carbon source } \\
\hline D-Amygdalin & 2 & + & + & + \\
\hline L-Arginine & 2 & + & + & + \\
\hline DL-Asparagine & 3 & - & - & - \\
\hline Dextrin & 5 & - & + & - \\
\hline Dulcitol & 3 & - & + & - \\
\hline Glycine & 2 & - & - & - \\
\hline Melibiose & - & + & + & + \\
\hline L-Proline & 3 & - & + & - \\
\hline Salicin & + & - & + & - \\
\hline Sodium formate & 2 & - & + & - \\
\hline L-Threonine & 2 & - & + & - \\
\hline Vanillic acid & 2 & - & - & - \\
\hline \multicolumn{5}{|c|}{ Substrates used as sole nitrogen source } \\
\hline DL-Threonine & 3 & - & - & - \\
\hline \multicolumn{5}{|l|}{ Resistance to $\left(\mu \mathrm{g} \mathrm{ml}^{-1}\right)$ : } \\
\hline Bacitracin (300) & + & + & - & - \\
\hline Erythromycin (100) & 3 & - & - & - \\
\hline Erythromycin (50) & 3 & + & + & + \\
\hline Kanamycin sulfate $(50)$ & 2 & - & - & - \\
\hline Neomycin sulfate $(50)$ & - & + & - & - \\
\hline Streptomycin sulfate (5) & + & + & - & + \\
\hline Tetracycline hydrochloride (5) & 1 & - & - & - \\
\hline Erythrosine blue $(0.1 \%)$ & - & + & - & - \\
\hline Methyl green $(0.1 \%)$ & - & + & - & - \\
\hline Sodium nitrite $(0.1 \%)$ & + & - & + & - \\
\hline $\mathrm{NaCl}(2 \%, \mathrm{w} / \mathrm{v})$ & 3 & - & - & - \\
\hline $\mathrm{pH} 10.0$ & 3 & - & + & - \\
\hline Nitrate reduction & + & - & + & + \\
\hline
\end{tabular}

45252, R. galegae HAMBI $540^{\mathrm{T}}$ and R. huautlense $\mathrm{S} 02^{\mathrm{T}}$, respectively. Fatty acids $\mathrm{C}_{12: 0} 3-\mathrm{OH}, \mathrm{C}_{15: 0}$ iso $3-\mathrm{OH}, \mathrm{C}_{15: 0}$ anteiso, $\mathrm{C}_{16: 0}$ iso, $\mathrm{C}_{16: 0}$ iso 3-OH, $\mathrm{C}_{16: 0}$ anteiso, $\mathrm{C}_{16: 1} \omega 11 c$, $\mathrm{C}_{17: 0}$ iso 3-OH, $\mathrm{C}_{18: 1} \omega 07 c$ 11-methyl and $\mathrm{C}_{18: 3} \omega 6 c$ were found only in strain CCBAU 45252 of the novel group with minor amounts (0.09-0.68\%).

Based on all the results obtained above, the seven new strains represent a novel species of the genus Rhizobium according to the current criteria for the description of rhizobial species (Graham et al., 1991; Wayne et al., 1987). This novel species could be differentiated by IGS-RFLP, fatty acid profiles, phenotypic characteristics, DNA-DNA relatedness and sequencing of the $a t p D, r e c A$ and $g \ln I I$ genes. The name Rhizobium vignae sp. nov. is proposed for this novel symbiotic bacterial species. Considering the apparent differences observed during the phenotypic characterization and in the cellular fatty acid determination between strains of $R$. vignae sp. nov., biovars or ecotypes may exist within this species.

\section{Description of Rhizobium vignae sp. nov.}

Rhizobium vignae (vi.gna'e. N.L. gen. n. vignae of Vigna, referring to the fact that the majority of strains were isolated from the mung bean, Vigna radiata).

Gram-negative rods $(0.5-0.7 \times 1.2-2.5 \mu \mathrm{m})$, aerobic and non-spore-forming. Colonies on YMA medium are circular, convex, white and opaque and usually have a diameter of $2-3 \mathrm{~mm}$ within $2-3$ days at $28{ }^{\circ} \mathrm{C}$. Grows on

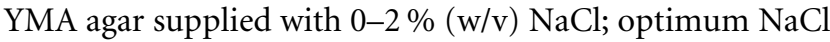
for growth is $1 \%$. Growth occurs at $10-40{ }^{\circ} \mathrm{C}$ and at $\mathrm{pH} 7-$ 10 on YMA plates, the optima are $28{ }^{\circ} \mathrm{C}$ and $\mathrm{pH} 7.0$. Catalase, urease and oxidase activities are present, but not phenylalanine 4-monooxygenase. Nitrate is reduced and reduction of methyl blue and Nile blue are observed. Acid production and reduction are observed in litmus milk. Resistant to $\left(\mu \mathrm{g} \mathrm{ml}^{-1}\right)$ : ampicillin (5), kanamycin sulfate (5), neomycin sulfate (5), streptomycin sulfate (5), bacitracin (300), erythromycin (100), chloramphenicol (5) and gentamicin sulfate (5). Grows on YMA supplied with Bismarck brown $(0.1 \%)$, Congo red $(0.1 \%)$, sodium nitrite $(0.1 \%)$ and sodium deoxycholate $(0.1 \%)$. The type strain utilizes D-arabinose, D-fructose, D-galactose, Dmannose, D-ribose, D-sorbitol, D-amygdalin, D-xylose, sodium DL-malate, glucose, calcium gluconate, dulcitol, inositol, L-rhamnose, L-proline, L-threonine, raffinose pentahydrate, salicin, sodium citrate, sodium D-gluconate, maltose, sodium pyruvate, sodium succinate, sodium acetate, sodium formate, sucrose, trehalose, syringic acid, vanillic acid, glycine and DL-asparagine as sole carbon sources for growth. The type strain uses almost all the sole nitrogen sources tested, including L-aspartic acid, (+)-Lglutamic acid, D-glutamic acid, L-alanine, DL-threonine, hypoxanthine, L-arginine, L-cystine, L-isoleucine, L-lysine, L-phenylalanine, L-threonine, L-methionine and L-valine. The type strain does not utilize adipic acid, dextrin, inulin, melezitose, melibiose, meso-erythritol, calcium malonate, sorbose, soluble starch, sodium tartrate, sodium hippurate, L-methionine or L-arginine. The common and/or main fatty acid compounds are $\mathrm{C}_{16: 0}, \mathrm{C}_{16: 0} \mathrm{~N}$ alcohol, $\mathrm{C}_{19: 0}$ cyclo $\omega 8 c$, summed feature $4\left(\mathrm{C}_{17: 1}\right.$ iso $\mathrm{I} /$ anteiso $\mathrm{B}$ and/or $\mathrm{C}_{17: 1}$ anteiso $\mathrm{B} /$ iso $\left.\mathrm{I}\right)$ and summed feature $8\left(\mathrm{C}_{18: 1} \omega 7 c\right.$ and/ or $\mathrm{C}_{18: 1} \omega 6 c$ ).

The type strain, CCBAU $05176^{\mathrm{T}}\left(=\right.$ HAMBI $3039^{\mathrm{T}}=\mathrm{LMG}$ $25447^{\mathrm{T}}$ ), was isolated from a root nodule of Astragalus dahuricus grown in Hebei Province, China. The DNA $\mathrm{G}+\mathrm{C}$ content of the type strain is $60.8 \mathrm{~mol} \%\left(T_{\mathrm{m}}\right)$. Additional strains were isolated from Astragalus dahuricus, A. oxyglottis, Vigna radiata and Desmodium microphyllum grown in different regions of China.

\section{Acknowledgements}

This work was supported by the foundation of the National Basic Research Program of China (2006CB100206). E. T.W. was supported by the project PICS08-3 authorized by ICyT D. F. and SIP20090179 and 20100067 authorized by IPN, México. 


\section{References}

de Lajudie, P., Willems, A., Nick, G., Moreira, F., Molouba, F., Hoste, B., Torck, U., Neyra, M., Collins, M. D. \& other authors (1998). Characterization of tropical tree rhizobia and descripftion of Mesorhizobium plurifarium sp. nov. Int J Syst Bacteriol 48, 369-382.

De Ley, J., Cattoir, H. \& Reynaerts, A. (1970). The quantitative measurement of DNA hybridization from renaturation rates. Eur J Biochem 12, 133-142.

Felsenstein, J. (1985). Confidence limits on phylogenies: an approach using the bootstrap. Evolution 39, 783-791.

Frank, B. (1889). Über die Pilzsysymbiose der Leguminosen. Ber Dtsch Bot Ges 7, 332-346.

Gao, J. L., Sun, J. G., Li, Y., Wang, E. T. \& Chen, W. X. (1994). Numerical taxonomy and DNA relatedness of tropical rhizobia isolated from Hainan province, China. Int J Syst Bacteriol 44, 151158.

Garcia-Fraile, P., Rivas, R., Willems, A., Peix, A., Martens, M., Martínez-Molina, E., Mateos, P. F. \& Velázquez, E. (2007). Rhizobium cellulosilyticum sp. nov., isolated from sawdust of Populus alba. Int J Syst Evol Microbiol 57, 844-848.

Gaunt, M. W., Turner, S. L., Rigottier-Gois, L., Lloyd-Macgilp, S. A. \& Young, J. P. W. (2001). Phylogenies of atpD and recA support the small subunit rRNA-based classification of rhizobia. Int J Syst Evol Microbiol 51, 2037-2048.

Graham, P. H., Sadowsky, M. J., Keyser, H. H., Barnet, Y. M., Bradley, R. S., Cooper, J. E., De Ley, D. J., Jarvis, B. D. W., Roslycky, E. B. \& other authors (1991). Proposed minimal standards for the description of new genera and species of root- and stem-nodulating bacteria. Int J Syst Bacteriol 41, 582-587.

Gu, J., Wang, E. T. \& Chen, W. X. (2007). Genetic diversity of rhizobia associated with Desmodium species grown in China. Lett Appl Microbiol 44, 286-292.

Hou, B. C., Wang, E. T., Li, Y., Jr, Jia, R. Z., Chen, W. F., Gao, Y., Dong, R. J. \& Chen, W. X. (2009). Rhizobium tibeticum sp. nov., a symbiotic bacterium isolated from Trigonella archiducis-nicolai (Sirj.) Vassilcz. Int J Syst Evol Microbiol 59, 3051-3057.

Jordan, D. C. (1984). Family III. Rhizobiaceae Conn (1938). 321 ${ }^{\mathrm{AL}}$. In Bergey's Manual of Systematic Bacteriology, vol. 1, pp. 234-254. Edited by N. R. Krieg \& J. G. Holt. Baltimore: The Williams \& Wilkins Co.

Jukes, T. H. \& Cantor, C. R. (1969). Evolution of protein molecules. In Mammalian protein metabolism, III, pp. 21-32. Edited by $\mathrm{H}$. N. Munro. New York: Academic Press.

Kimura, M. (1983). The Neutral Theory of Molecular Evolution. Cambridge: Cambridge University Press.

Kwon, S. W., Park, J.-Y., Kim, J.-S., Kang, J. W., Cho, Y. H., Lim, C. K., Parker, M. A. \& Lee, G. B. (2005). Phylogenetic analysis of the genera Bradyrhizobium, Mesorhizobium, Rhizobium and Sinorhizobium on the basis of $16 \mathrm{~S}$ rRNA gene and internally transcribed spacer region sequences. Int J Syst Evol Microbiol 55, 263-270.

Lin, D. X., Chen, W. F., Wang, F. O., Hu, D., Wang, E. T., Sui, X. H. \& Chen, W. X. (2009). Rhizobium mesosinicum sp. nov., isolated from root nodules of three different legumes. Int J Syst Evol Microbiol 59, 1919-1923.

Lindström, K. (1989). Rhizobium galegae, a new species of legume root nodule bacteria. Int J Syst Bacteriol 39, 365-367.

Lu, Y. L., Chen, W. F., Han, L. L., Wang, E. T. \& Chen, W. X. (2009). Rhizobium alkalisoli sp. nov., isolated from Caragana intermedia growing in saline-alkaline soils in the north of China. Int J Syst Evol Microbiol 59, 3006-3011.
Marmur, J. (1961). A procedure for isolation of deoxyribonucleic acid from microorganisms. J Mol Biol 3, 208-218.

Marmur, J. \& Doty, P. (1962). Determination of the base composition of deoxyribonucleic acid from its thermal denaturation temperature. J Mol Biol 5, 109-118.

Martens, M., Dawyndt, P., Coopman, R., Gillis, M., De Vos, P. \& Willems, A. (2008). Advantages of multilocus sequence analysis for taxonomic studies: a case study using 10 housekeeping genes in the genus Ensifer (including former Sinorhizobium). Int J Syst Evol Microbiol 58, 200-214.

Peng, G. X., Tan, Z. Y., Wang, E. T., Reinhold-Hurek, B., Chen, W. F. \& Chen, W. X. (2002). Identification of isolates from soybean nodules in Xinjiang Region as Sinorhizobium xinjiangense and genetic differentiation of S. xinjiangense from Sinorhizobium fredii. Int J Syst Evol Microbiol 52, 457-462.

Quan, Z. X., Bae, H. S., Baek, J. H., Chen, W. F., Im, W. T. \& Lee, S. T. (2005). Rhizobium daejeonense sp. nov. isolated from a cyanide treatment bioreactor. Int J Syst Evol Microbiol 55, 2543-2549.

Rasolomampianina, R., Bailly, X., Fetiarison, R., Rabevohitra, R., Béna, G., Ramaroson, L., Raherimandimby, M., Moulin, L., De Lajudie, P. \& other authors (2005). Nitrogen-fixing nodules from rose wood legume trees (Dalbergia spp.) endemic to Madagascar host seven different genera belonging to alpha- and betaProteobacteria. Mol Ecol 14, 4135-4146.

Saitou, N. \& Nei, M. (1987). The neighbor-joining method: a new method for reconstructing phylogenetic trees. Mol Biol Evol 4, 406-425.

Tamura, K., Dudley, J., Nei, M. \& Kumar, S. (2007). MEGA4: Molecular evolutionary genetics analysis (MEGA) software version 4.0. Mol Biol Evol 24, 1596-1599.

Tan, Z. Y., Xu, X. D., Wang, E. T., Gao, J. L., Martinez-Romero, E. \& Chen, W. X. (1997). Phylogenetic and genetic relationships of Mesorhizobium tianshanense and related rhizobia. Int J Syst Bacteriol 47, 874-879.

Terefework, Z., Kaijalainen, S. \& Lindström, K. (2001). AFLP fingerprinting as a tool to study the genetic diversity of Rhizobium galegae isolated from Galega orientalis and Galega officinalis. J Biotechnol 91, 169-180.

Tighe, S. W., de Lajudie, P., Dipietro, K., Lindström, K., Nick, G. \& Jarvis, B. D. W. (2000). Analysis of cellular fatty acids and phenotypic relationships of Agrobacterium, Bradyrhizobium, Mesorhizobium, Rhizobium and Sinorhizobium species using the Sherlock Microbial Identification System. Int J Syst Evol Microbiol 50, 787-801.

Turner, S. L. \& Young, J. P. W. (2000). The glutamine synthetases of rhizobia: phylogenetics and evolutionary implications. Mol Biol Evol 17, 309-319.

van Berkum, P., Elia, P. \& Eardly, B. D. (2006). Multilocus sequence typing as an approach for population analysis of Medicago-nodulating rhizobia. J Bacteriol 188, 5570-5577.

Vandamme, P., Vancanneyt, M., van Belkum, A., Segers, P., Quint, W. G., Kersters, K., Paster, B. J. \& Dewhirst, F. E. (1996). Polyphasic analysis of strains of the genus Capnocytophaga and Centers for Disease Control group DF-3. Int J Syst Bacteriol 46, 782-791.

Vincent, J. M. (1970). A Manual for the Practical Study of Root-Nodule Bacteria. Oxford, UK: Blackwell Scientific Publications.

Wang, E. T., van Berkum, P., Beyene, D., Sui, X. H., Dorado, O., Chen, W. X. \& Martínez-Romero, E. (1998). Rhizobium huautlense sp. nov., a symbiont of Sesbania herbacea that has a close phylogenetic relationship with Rhizobium galegae. Int $J$ Syst Bacteriol 48, 687-699.

Wayne, L. G., Brenner, D. J., Colwell, R. R., Grimont, P. A. D., Kandler, O., Krichevsky, M. I., Moore, L. H., Moore, W. E. C., Murray, R. G. E. \& other authors (1987). Report of the ad hoc committee on 
reconciliation of approaches to bacterial systematics. Int $J$ Syst Bacteriol 37, 463-464.

Yan, A. M., Wang, E. T., Kan, F. L., Tan, Z. Y., Sui, X. H., Reinhold-Hurek, B. \& Chen, W. X. (2000). Sinorhizobium meliloti associated with Medicago sativa and Melilotus spp. in arid saline soils in Xinjiang, China. Int J Syst Evol Microbiol 50, 1887-1891.

Zhang, Y. F., Wang, F. Q. \& Chen, W. X. (2006). Numerical taxonomy and $16 \mathrm{~S}$ rDNA PCR-rFLP analysis of rhizobial strains isolated from root nodules of cowpea and mung bean grown in different regions of China. Wei Sheng Wu Xue Bao 46, 861-868 (in Chinese).

Zhao, C. T., Wang, E. T., Chen, W. F. \& Chen, W. X. (2008). Diverse genomic species and evidences of symbiotic gene lateral transfer detected among the rhizobia associated with Astragalus species grown in the temperate regions of China. FEMS Microbiol Lett 286, 263-273. 